\section{Heat Treatment Affects Epicuticular Wax Structure and Postharvest Calcium Uptake in 'Golden Delicious' Apples}

\author{
Stéphane Roy \\ Horticultural Crops Quality Laboratory and Electron Microscopy Laboratory, \\ Beltsville Agricultural Research Center, Agricultural Research Service, U.S. \\ Department of Agriculture, Beltsville, MD 20705
}

William S. Conway and Alley E. Watada

Horticultural Crops Quality Laboratory, Beltsville Agricultural Research Center, Agricultural Research Service, U.S. Department of Agriculture, Beltsville, MD 20705

\section{Carl E. Sams}

Department of Plant and Soil Science, The University of Tennessee, Knoxville, TN 37901

\section{Eric F. Erbe and William P. Wergin \\ Electron Microscopy Laboratory, Beltsville Agricultural Research Center, Agricultural Research Service, U.S. Department of Agriculture, Beltsville, MD 20705}

\begin{abstract}
Additional index words. $\mathrm{CaCl}_{2}$, low-temperature scanning electron microscopy, Malus domestica, pressure infiltration
\end{abstract}

\begin{abstract}
Golden Delicious' apples (Malus domestica Borkh) were pressure-infiltrated at harvest with a $4 \% \mathrm{CaCl}_{2}$ solution either without prior heat treatment or following 4 days at 38C. Examination of the apple surfaces from both treatments by low-temperature scanning electron microscopy revealed that heat treatment changed the pattern of epicuticular wax. The epicuticular wax of nonheated fruit exhibited numerous deep surface cracks that formed an interconnected network on the fruit surface. The epicuticular wax of heat-treated fruit did not exhibit a similar network of deep cracks. This apparent obstruction or elimination of deep cracks may limit the $\mathrm{CaCl}_{2}$ solutions from entering the fruit. The heated fruit contained significantly less $\mathrm{Ca}$ than the fruit that were pressureinfiltrated with $\mathrm{CaCl}_{2}$ solutions but not heated. These results indicate that cracks on the fruit surface may be an important pathway for the penetration of $\mathrm{CaCl}_{2}$ solutions.
\end{abstract}

Losses caused by postharvest pathological and physiological maladies, due to the added cost of harvesting and handling, are economically greater than equivalent preharvest losses. Growing consumer concern about pesticide residues on the surface of produce is prompting the development of alternative methods of maintaining the quality of fruit during storage. One of these methods, prestorage heat treatment of apples, has had a positive effect on fruit quality in storage. Exposing apples to 38 to $40 \mathrm{C}$ for 2 to 6 days suppressed softening and reduced naturally occurring decay (Liu, 1978; Porritt and Lidster, 1978).

Received for publication 5 Jan. 1994. Accepted for publication 24 Apr. 1994. We express our appreciation to George A. Brown and William B. Beavers for valuable technical assistance. Use of a company name or product by the U.S. Dept. of Agriculture does not imply approval or recommendation of the product to the exclusion of others that also may be suitable. The cost of publishing this paper was defrayed in part by the payment of page charges. Under postal regulations, this paper therefore must be hereby marked advertisement solely to indicate this fact.
Postharvest treatment of apples with $\mathrm{CaCl}_{2}$ solutions and the resulting increase in fruit flesh $\mathrm{Ca}$ concentration also beneficially affected fruit during storage. Firmness was maintained and decay caused by a variety of postharvest pathogens was reduced as a result of the increased Ca concentration (Conway and Sams, 1983; Conway et al., 1991; Sams and Conway, 1984).

In a recent study, nonheated apples dipped in a $\mathrm{CaCl}_{2}$ solution had a higher $\mathrm{Ca}$ concentration than apples that were heat-treated before Ca treatment (Lurie and Klein, 1992). In another study, the Ca concentration of apples that were pressure-infiltrated with $\mathrm{CaCl}_{2}$ solutions was also higher in nonheated than in heat-treated apples (Sams et al., 1993).

The present study examines the effect of heat treatment of 'Golden Delicious' apples on uptake of $\mathrm{CaCl}_{2}$ solutions upon pressure infiltration and the relationship of uptake to the morphology of the epicuticular wax surface of the fruit. Recent improvements in a technique referred to as low-temperature scanning electron microscopy (SEM) allowed us to observe the waxy surface of the apple fruit in a frozen hydrated state. Low-temperature SEM avoided the preparation artifacts that are associated with normal SEM studies, i.e., mechanical damage from chemical processing, dissolution from dehydration, and shrinkage during critical-point drying (for a complete discussion see Jeffree and Read, 1991). Moreover, cryofixation improves preservation of the delicate structure of the wax platelets of epicuticular waxes (Roy et al., 1994). Because cryofixation stabilizes tissues faster than chemical fixation (Wergin and Erbe, 1991, 1992), the surface of the fruit can be preserved and observed immediately after heat treatment.

\section{Materials and Methods}

'Golden Delicious' apples were harvested in the preclimactaric stage (ethylene production was $<0.1 \mu \mathrm{l} \cdot$ liter $^{-1}$ and the climactaric rise in the $\mathrm{CO}_{2}$ level had not yet begun) from a commercial orchard and randomized into two lots. One lot was pressure-infiltrated ( $3 \mathrm{~min}$ at $103 \mathrm{kPa})$ with distilled water $\left(0 \% \mathrm{CaCl}_{2}\right)$ or with a $4 \%$ solution of $\mathrm{CaCl}_{2}$. The second lot of fruit was tray-packed into boxes with perforated polyethylene liners and heated for 4 days at $38 \mathrm{C}$. The fruit were then removed and pressure-infiltrated ( $3 \mathrm{~min}$ at $103 \mathrm{kPa}$ ) with distilled water $\left(0 \% \mathrm{CaCl}_{2}\right)$ or a $4 \%$ solution of $\mathrm{CaCl}_{2}$.

To determine the Ca content of the apple tissue, a mechanical peeler removed the peel and outer flesh of the entire fruit to a depth of $2 \mathrm{~mm}$. This portion was discarded. Then the peeler was used to remove the next $2 \mathrm{~mm}$ of flesh, which was retained for $\mathrm{Ca}$ analysis. Each sample consisted of flesh from five apples, and each treatment contained four samples.

The flesh that was removed from the fruit for $\mathrm{Ca}$ analysis was immediately frozen in liquid N, freeze-dried, and ground. One gram of ground tissue from each sample was dryashed and dissolved in $2 \mathrm{~N}$ hydrochloric acid. The samples were then analyzed for Ca using plasma emission spectrometry. Calcium concentration is reported on a dry-weight basis.

An Oxford CT 1500 Cryotrans System (Oxford Instruments, Eynsham, England) interfaced to a Hitachi S-4100 field emission SEM was used to observe the surfaces of heattreated and nonheated (control) fruit. Segments of flesh with skin were removed from the fruit immediately after heat treatment and placed on a flat specimen holder as described by Roy et al. (1994). The holder was rapidly plunged into liquid $\mathrm{N}$ and cryotransferred, under vacuum, to a cold stage in the prechamber of the cryosystem. The frozen specimens were etched in the prechamber by raising the temperature of the stage to $-90 \mathrm{C}$ for $8 \mathrm{~min}$. This process sublimed some of the surface water ice. The specimens were then sputter-coated with Pt in the prechamber and transferred to the cryostage in the SEM for observations.

The experiment was a $2 \times 2$ factorial in a randomized complete-block design with two heat treatments, two Ca treatments, and three 20 -fruit replications. Analysis of variance was performed using the General Linear Models Procedure (SAS Institute, 1988). Treatments 
that were statistically different at $P \leq 0.05$ are reported as significant.

\section{Results and Discussion}

Heated and nonheated fruit treated with distilled water were not significantly different in tissue $\mathrm{Ca}$ concentration and averaged $\approx 130$ $\mu \mathrm{g} \cdot \mathrm{g}^{-1}$ dry weight (Fig. 1). Infiltration with a $4 \%$ solution of $\mathrm{CaCl}_{2}$ resulted in fruit with a significantly higher Ca content than was found in control fruit. Furthermore, the fruit that were not heated but infiltrated had a significantly higher Ca concentration $\left(2090 \mu \mathrm{g} \mathrm{g}^{-1}\right.$ dry weight) than fruit that were heated before infiltration $\left(1363 \mu \mathrm{g} \cdot \mathrm{g}^{-1} \mathrm{dry}\right.$ weight $)$. Thus, the tissue from the nonheated fruit had $\approx 50 \%$ more $\mathrm{Ca}$ than that from the heated fruit. These results confirm previous experiments with heattreated 'Golden Delicious' apples (Sams et al., 1993) and suggest an effect of heat treatment on the surface morphology of the fruit.

Calcium in postharvest treatments enters the fruit primarily through the lenticels (Betts and Bramlage, 1977; Glenn et al., 1985); however, cracks in the cuticle and epidermis may also provide pathways, especially in lateharvested fruit (Clements, 1935). 'Golden Delicious' apples have a high degree of cracking in the cuticle and skin (Meyer, 1944). Faust and Shear (1972), who studied the structure and cracks of the epicuticular wax of 'Golden Delicious' apple fruit, found that early in the growing season, the cracks were quite deep and extended through the wax layer. By the end of the growing season, the cracks on the surface of the fruit were larger and formed a network on the surface.

Low-temperature SEM provided a structural basis for the effect of heat treatment. The epicuticular wax of the nonheated fruit appeared relatively smooth but exhibited numerous surface cracks that formed an interconnected network on the surface of the fruit (Fig. 2A). At a higher magnification, the cracks appeared deep and traversed through two or three layers of wax platelets (Fig. 2B). These cracks may occur naturally as a result of fruit expansion during development and ripening.

The epicuticular wax of heat-treated fruit did not exhibit a network of cracks at low magnification (compare Fig. $2 \mathrm{~A}$ and C). Although the surface contained a waxy cuticle, the individual platelets appeared more randomly organized (Fig. 2D), rather than being disposed in parallel layers (Fig. 2B). This observation was especially true for areas that were thought to correspond to the deep cracks in the nonheated fruit; these areas had an abundance of plate-like wax crystals, which were predominantly oriented perpendicular to the surface of the cuticle. As a result of the heat treatment, perhaps a recrystallization or "melting" of the wax platelets occurred in the cracks. Alternatively, the heat treatment may have stimulated an increase in the synthesis of wax to fill the cracks, lenticels, or both. Other investigations using controlled environmental conditions have indicated that temperature affects the quantity and structure of the epicuticular wax and that the shape of wax crystals

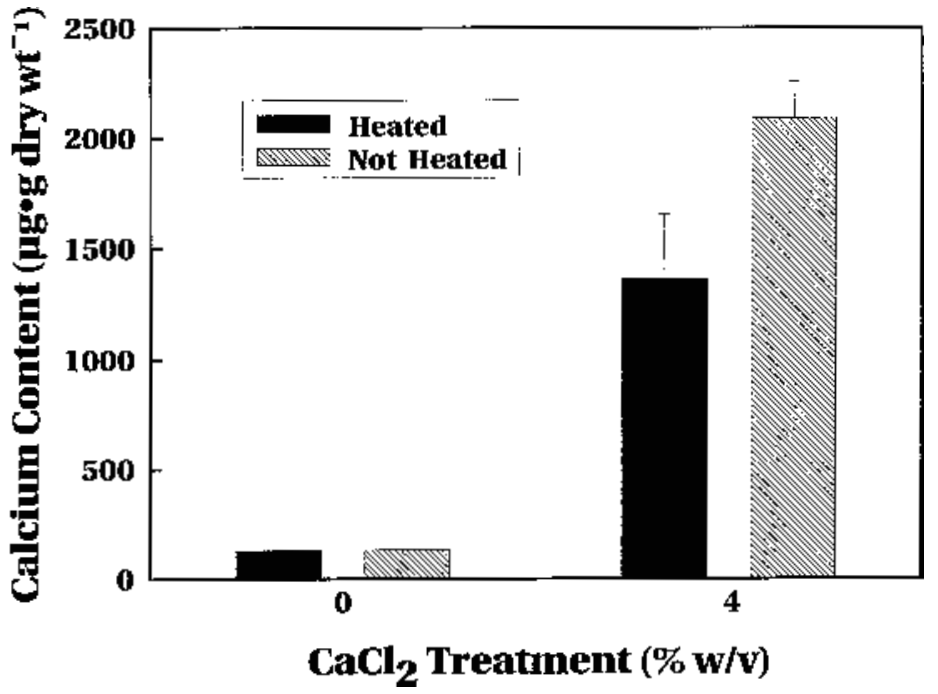

Fig. 1. Calcium content of 'Golden Delicious' apples following heat treatment and $\mathrm{CaCl}_{2}$ infiltration. Fruit were pressure-infiltrated $(3 \mathrm{~min} ; 103 \mathrm{kPa})$ with distilled water $\left(0 \% \mathrm{CaCl}_{2}\right)$ or a $4 \%$ solution of $\mathrm{CaCl}_{2}$ or heat-treated at $38 \mathrm{C}$ for 4 days before pressure infiltration with $0 \%$ or $4 \% \mathrm{CaCl}_{2}$. Vertical bars represent standard errors of means.

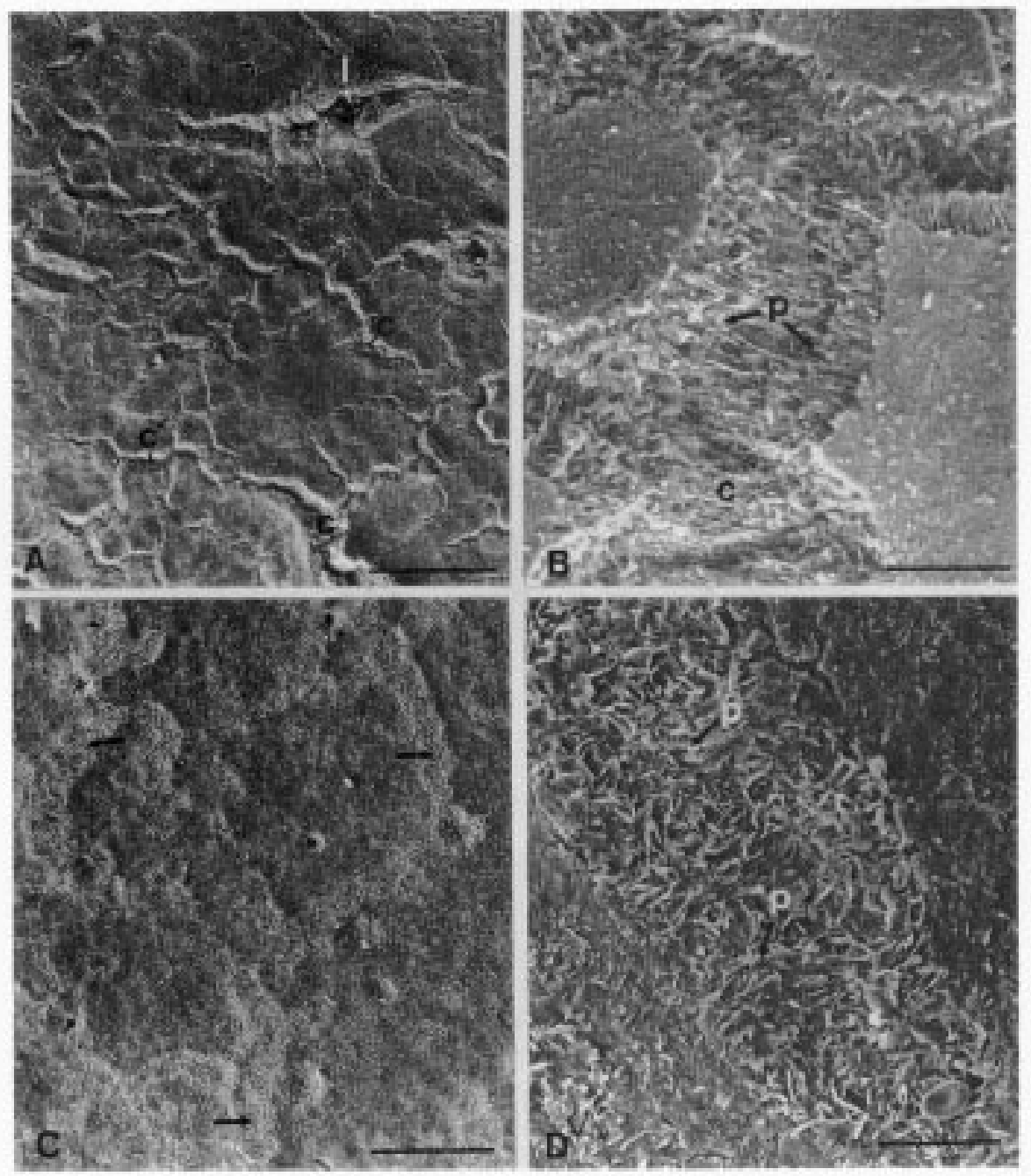

Fig. 2. Epicuticular wax of 'Golden Delicious' apple fruit examined with a low-temperature scanning electron microscope. A and $\mathbf{B}$ are nonheated fruit. Deep cracks appear on the surface of the fruit. These cracks (c) form an interconnected network. Deeper and wider cracks are seen around the lenticels (I). A $(\times 75)$, bar $=200 \mu \mathrm{m} ; \mathbf{B}(\times 650)$, bar $=20 \mu \mathrm{m}$. C and $\mathbf{D}$ are heat-treated fruit. The surface appears smoother, and no deep cracks are visible. However, perpendicularly oriented wax platelets (p) appear in areas that may coincide with the cracks in the nonheated fruit. $\mathbf{C}(\times 75)$, bar $=200 \mu \mathrm{m} ; \mathbf{D}(\times 650)$, bar $=20 \mu \mathrm{m}$. 
is strongly correlated with their chemistry (Jeffree and Sandford, 1982). Baker (1974) suggested that increases in temperature stimulate wax production. Obstructing or eliminating the cracks would limit infiltration of $\mathrm{CaCl}_{2}$ solutions into the fruit. As a result, heated fruit would contain significantly less $\mathrm{Ca}$ than nonheated fruit following pressure infiltration with $\mathrm{CaCl}_{2}$ solutions. Studies conducting structural and physiological investigations in parallel can contribute to the understanding of the pathways involved in Ca penetration. Our results indicate that cuticular cracks may be important for postharvest Ca penetration into apple fruit. To elucidate the complex movement of Ca through the cuticle, further studies are needed to relate the behavior of these cracks during storage to $\mathrm{Ca}$ uptake and postharvest fruit quality.

\section{Literature Cited}

Baker, E.A. 1974. The influence of environment on leaf wax development in Brassica oleracea gemmifera. New Phytol. 73:955-966.

Betts, H.A. and W.J. Bramlage. 1977. Uptake of calcium by apples from postharvest dips in calcium chloride solutions. J. Amer. Soc. Hort. Sci. 102:785-788.

Clements, H.F. 1935. Morphology and physiology of the pome lenticels of Pyrus malus. Bot. Gaz. 97:101-117.

Conway, W.S. and C.E. Sams. 1983. Calcium infiltration of 'Golden Delicious' apples and its effect on decay. Phytopathology 73:1068-1071.

Conway, W.S., C.E. Sams, J.A. Abbott, and B.D. Bruton. 1991. Postharvest calcium treatment of apple fruit to provide broad-spectrum protection against postharvest pathogens. Plant Dis. 75:620-622.

Faust, M. and C.B. Shear. 1972. Fine structure of the fruit surface of three apple cultivars. J. Amer. Soc. Hort. Sci. 97:351-355.

Glenn, G.M., B.W. Poovaiah, and H.P. Rasmussen 1985. Pathways of calcium penetration through isolated cuticles of 'Golden Delicious' apple fruit. J. Amer. Soc. Hort. Sci. 110:166-171.

Jeffree, C.E. and N.D. Read. 1991. Ambient and low-temperature scanning electron microscopy, p. 313-414. In: J.L. Hall and C. Hawes (eds.). Electron microscopy of plant cells. Academic, London.

Jeffree, C.E. and A.P. Sandford. 1982. Crystalline structure of plant epicuticular waxes demonstrated by cryostage scanning electron microscopy. New Phytol. 91:549-559.

Liu, F.W. 1978. Modification of apple quality by high temperature. J. Amer. Soc. Hort. Sci. 103:730-732.

Lurie, S. and J.D. Klein. 1992. Calcium and heat treatments to improve storability of 'Anna' apples. HortScience 27:36-39.
Meyer, A. 1944. A study of the skin structure of 'Golden Delicious' apples. Proc. Amer. Soc. Hort. Sci. 45:723-727.

Porritt, S.W. and P.D. Lidster. 1978. The effect of pre-storage heating on ripening and senescence of apples during cold storage. J. Amer. Soc. Hort. Sci. 103:584-587.

Roy, S., A.E. Watada, W.S. Conway, E.F. Erbe, and W.P. Wergin. 1994. Low-temperature scanning electron microscopy of frozen hydrated apple tissues and surface organisms. HortScience 29:305-309.

Sams, C.E. and W.S. Conway. 1984. Effect of calcium infiltration on ethylene production, respiration rate, soluble polyuronide content, and quality of 'Golden Delicious' apple fruit. J. Amer. Soc. Hort. Sci. 109:53-57.

Sams, C.E., W.S. Conway, J.A. Abbott, R.J. Lewis, and N. Ben-Shalom. 1993. Firmness and decay of apples following postharvest pressure infiltration of calcium and heat treatment. J. Amer. Soc. Hort. Sci. 118:623-627.

SAS Institute. 1988. SAS/STAT user's guide release 6.03. SAS Inst., Cary, N.C.

Wergin, W.P. and E.F. Erbe. 1991. Introduction to the advantages and problems associated with low temperature scanning electron microscopy. Scanning 13:24-26.

Wergin, W.P. and E.F. Erbe. 1992. Recent advancements in low temperature scanning electron microscopy. Scanning (suppl.) 14:40-42. 